\title{
PROGRAM DIRECT MARKETING DWI-BAHASA GUNA MENINGKATKAN MINAT WISATA RELIGI MAKAM MBAH HONGGO, KAMPUNG KAYUTANGAN, KOTA MALANG
}

\author{
Rulli Krisnanda \\ Program Diploma Kepariwisataan Universitas Merdeka Malang \\ Jl. Bandung No. 1 Malang
}

Korespondensi dengan Penulis:

Rulli Krisnanda: Telp: 6282234027555

E-mail: rulli.krisnanda@gmail.com

\begin{abstract}
Malang city has many tourist destinations. Some of them are located in Malang's downtown. One of the city's existing tourism potential is owned by the city of Malang, namely Kayutangan Village. Areas that have a religious tourist attraction located Jl. Basuki Rachmad Gg.4, RW 09 which is Mbah Honggo Koesomo's tomb. But there are still many people who do not know the existence of this tourist destination. Therefore, there should be a bilingual direct marketing program to increase the religious tourism interest of Mbah Honggo's tomb, Kayutangan Village, Malang City. Parties which expect to assist in term of implementing direct-marketing methods to increase tourist interest in mbah Honggo's tomb is the Tourism Office of Malang City, government or officials in Kayutangan village, the family welfare movement or in Indonesian's term, we call as PKK (Pembinaan Kesejahteraan Keluarga) in Kayutangan village, and the surrounding community of Mbah Honggo's tomb. Steps that can be taken are preparation of information gathering, marketing tool making in the form of guide book, marketing and language marketing training, direct-marketing implementation and evaluation.
\end{abstract}

Keywords: Kayutangan, Mbah Honggo tomb, direct-marketing, bilingual

Saat ini dunia pariwisata sudah menjadi sebuah industri yang berkembang untuk mendapatkan keuntungan sebesar-besarnya. Perkembangan dunia pariwisata didukung dengan semakin kondusifnya kondisi dan tatanan topografi di daerah tersebut. Selain aspek terbut, proses pemasaran (marketing) pariwisata juga diperlukan supaya wisatawan lebih mudah mengenali daerah tersebut. Informasi yang aktual dan persuasif diperlukan untuk membuat suatu destinasi wisata menjadi menarik dan diminati oleh wisatawan. Marketing atau pemasaran adalah suatu cara dalam menjalankan suatu "usaha" dengan lebih menitikberatkan perhatian terhadap pelanggan daripada terhadap produk. 
Semua fungsi manajemen termasuk pengorganisasian, perencanaan, pengambilan keputusan dan pengawasan terhadap hasil-hasilnya, diarahkan kepada orientasi pemasaran yang mewujudkan suatu kumpulan teknik dan strategi guna mencapai tujuan-tujuan.

Krippendorf, dalam bukunya Marketing et Tourisme, memberikan batasan pemasaran wisata sebagai berikut: "Penyesuaian yang sistematis dan terkoordinasi mengenai kebijakan dari badan-badan usaha wisata maupun kebijakan dalam sektor pariwisata pada tingkat pemerintah, lokal, regional, nasional dan internasional, guna mencapai suatu titik kepuasan optimal bagi kebutuhan-kebutuhan kelompok pelanggan tertentu yang telah ditetapkan sebelumnya, sekaligus untuk mencapai tingkat keuntungan yang memadai.

Dalam suatu proses pemasaran dibutuhkan suatu komunikasi. Suksesnya kegiatan pemasaran yang dilakukan suatu perusahaan tidak hanya bergantung pada kualitas produk yang dihasilkannya, kebijaksanaan yang tepat, pelayanan serta distribusi yang cepat, tetapi banyak tergantung pada pembinaan hubungan antara produsen dan konsumen yang berkelanjutan. Oleh karena itu suatu komunikasi dalam pemasaran atau marketing harus bersifat informatif dan persuasif.

Kota - kota besar seringkali menjadi destinasi wisata bagi pengunjung dari luar kota. Saat ini, sektor pariwisata menjadi faktor penentu kelahiran kembali suatu kota. Konsep perkotaan yang dijadikan sebagai destinasi wisata dapat memiliki kontribusi besar bagi pertumbuhan industri wisata yang potensial di setiap kota. Destinasi wisata di kota Malang mempunyai keanekaragaman jenis mulai dari wisata alam, sejarah, religi, petualangan sampai kuliner. Malang mempunyai kekayaan dan keanekaragaman tersebut yang bisa dimanfaatkan potensinya untuk menarik wisatawan domestic maupun wisatawan manca negara.Penelitian menurut Vella dan Nedelea (2008) menyebutkan bahwa sektor pariwisata kota dapat berkontribusi dalam dua hal, yaitu peningkatan perekonomian, 
meningkatkan investasi produk dan infrastruktur budaya, serta dapat meningkatkan kualitas hidup masyarakat sekitarnya. Sebuah kota yang menjadi wisata kota dapat meningkatkan potensi sumberdaya yang dimiliki.

Oleh karena itu, pengembangan perkotaan, arsitektur dan fungsional kota dapat menjadi titik fokus dari banyaknya upaya pembangunan. Apabila pariwisata kota direncanakan dengan benar, dikembangkan dan dikelola dengan baik, dapat membuat keuntungan dan dapat memberikan multiple-effect bagi masyarakatnya. Tingginya minat wisata kota disebabkan oleh informasi dan publisitas pariwisata yang memungkinkan pengunjung untuk mengetahui dan mengintegrasikan ke sekitarnya. Tren terbaru dalam pariwisata yaitu mulai banyak wisatawan yang mengunjungi perkotaan sebagai salah satu daya tarik wisata.

Seiring dengan minat wisatawan akan wisata kota, maka akan timbul tantangan besar bagi Kota Malang sebagai kota pariwisata harus mampu merespon harapan dan kebutuhan wisatawan untuk meningkatkan jumlah wisatawan dengan cara menggali daya tarik dan produk wisata yang dimiliki. Para stakeholderyang mempunyai produk pariwisata harus selalu melakukan perbaikan dan pengembangan fasilitas wisata untuk menciptakan kota pariwisata yang kompetitif. Selain itu, sebuah kota juga harus memastikan pariwisata yang dikembangkan dan dikelola sedemikian rupa, sehingga dapat memberikan kontribusi yang signifikan bagi masyarakat sekitar tanpa mengabaikan kerusakan lingkungan.

Di Indonesia sudah banyak kota yang dijadikan sebagai wisata kota dan telah berkembang, salah satunya yang sedang dikembangkan adalah pariwisata Kota Malang. Kota Malang merupakan salah satu kota di Provinsi Jawa Timur di Indonesia yang memliki banyak potensi untuk dijadikan sebagai destinasi wisata yang dapat dikunjungi oleh para wisatawan nusantara maupun mancanegara. Akan tetapi, sayangnya kota Malang seringkali hanya 
dijadikan kota transit bagi para wisatawan karena para wisatawan lebih memilih untuk berwisata ke kota Batu maupun Malang Selatan dan Taman Nasional Bromo Tengger Semeru yang terkenal akan jajaran pantai-pantainya. Padahal sebenarnya kota Malang sendiri menyimpan destinasi wisata sejarah dan religi dimana banyak masyarakat belum mengetahuinya.

Salah satu potensi wisatakota yang ada dimiliki oleh kota Malang yaitu Kampung Kayutangan. Area Kayutangan tersebar luas mulai dari Jalan Basuki Rachmad, Jalan Kahuripan sampai Pasar Bunga dan Pasar Hewan Splendid. Akan tetapi, wilayah yang mempunyai daya tarik wisata religi terletak Jl. Basuki Rachmad Gg.4, RW 09 yakni berupa Makam Mbah Honggo Koesomo. Terdapat beberapa versi mengenai Makam Mbah Honggo Koesomo, beberapa sumber menyebutkan Mbah Honggo adalah salah satu senopati Pangeran Diponegoro yang pindah ke Malang pada tahun 1830 untuk menghindari penangkapan oleh Belanda. Ada pula yang menyebutkan
Mbah Honggo adalah keturunan Kerajaan Mataram yang menjadi penyebar agam Islam di wilayah Kayutangan yang dulunya masih berupa hutan. Selain Makam Mbah Honggo, di kampung tersebut juga mempunyai makam Kanjeng Soero Adimerto atau Kyai Ageng Peroet yang merupakan keturunan Prabu Wijaya dari kerajaan Majapahit. Kampung Kayutangan tidak hanya menyimpan wisata religi saja akan tetapi juga wisata heritage yang masih tersimpan di beberapa rumah-rumah penduduk yang umur bangunannya sudah cukup tua akan tetapi pondasi bangunannya masih kokoh. Warga Kayutangan sendiri mengakui bahwa kawasan wisata makam Mbah Honggo tersebut masih belum banyak dikenal oleh wisatawan bahkan warga Kota Malang sekalipun. Oleh karena itu perlu adanya suatu strategi pemasaran atau marketing untuk mengembangkan kawasan wisata tersebut.

\section{METODE}


Jenis Artikel ini adalah deskriptif kualitatif yang bertujuan untuk mengumpulkan informasi secara actual melalui observasi dan wawancara langsung, mengidentifikasikan masalah, memeriksa kondisi dan menyusun gaagsan berdasarkan teori-teori atau kajian putaka yang telah dipaparkan. Sumber data yang didapat adalah melalui studi kepustakaan.

\section{HASIL DAN PEMBAHASAN}

Salah satu potensi wisatakota yang ada dimiliki oleh kota Malang yaitu Kampung Kayutangan. Area Kayutangan tersebar luas mulai dari Jalan Basuki Rachmad, Jalan Kahuripan sampai Pasar Bunga dan Pasar Hewan Splendid. Akan tetapi, wilayah yang mempunyai daya tarik wisata religi terletak Jl. Basuki Rachmad Gg.4, RW 09 yakni berupa Makam Mbah Honggo Koesomo. Terdapat beberapa versi mengenai Makam Mbah Honggo Koesomo, beberapa sumber menyebutkan Mbah Honggo adalah salah satu senopati Pangeran Diponegoro yang pindah ke Malang pada tahun 1830 untuk menghindari penangkapan oleh Belanda. Ada pula yang menyebutkan Mbah Honggo adalah keturunan Kerajaan Mataram yang menjadi penyebar agam Islam di wilayah Kayutangan yang dulunya masih berupa hutan. Selain Makam Mbah Honggo, di kampung tersebut juga mempunyai makam Kanjeng Soero Adimerto atau Kyai Ageng Peroet yang merupakan keturunan Prabu Wijaya dari kerajaan Majapahit. Kampung Kayutangan tidak hanya menyimpan wisata religi saja akan tetapi juga wisata heritage yang masih tersimpan di beberapa rumah-rumah penduduk yang umur bangunannya sudah cukup tua akan tetapi pondasi bangunannya masih kokoh. Selain makam Mbah Honggo, masih terdapat makam-makam lainnya yang dianggap sebagai pengikut atau penganut dari ajaran mbah Honggo. Namun pada kenyataanya, masih banyak wisatawan yang belum mengetahui keberadaan wisata religi tersebut bahkan waqrga Kota Malang sendiri masih banyak yang belum mengetahuinya. 
Oleh karena itu dibutuhkan suatu teknik pemasaran wisata yang baik supaya wisatawan baik domestik maupun wisatawan asing mengenal dan meminati makam Mbah Honngo ini sebagai salah satu destinasi tujuan wisata di Kota Malang. Salah satu teknik yang bisa diaplikasikan adalah melalui direct marketing. Direct marketing adalah pemasaran yang dilakukan dengan caraterjun langsung pada sasaran pemasaran baik itu dalam bentuk individu, kelompok maupun institusi.

Direct Marketing memiliki kelebihan dimana produsen bisa bertatap muka langsung dengan konsumen. Oleh karena itu dalam teknik pemasaran tersebut dibutuhkan komunikasi yang baik karena bertujuan untuk mempengaruhi potential-customers. Oleh karena itu suatu komunikasi dalam direct marketing harus bersifat informatif dan persuasif. Selain itu, dalam direct marketing perlu diperhatikan mengenai komunikasi non-verbal sebab komunikasi non-verbal harus memberikan kesan favorable terhadap sasaran marketing dalam hal ini adalah wisatawan. Bila pemasaran ditinjau dari dari segi ini, maka yang termasuk dalam kegiatan ini adalah public relation, advertising dan sales support. Selain aspek-aspek di atas kemampuan berbahasa juga perlu ditingkatkan dalam hal ini paling tidak bahasa nasional dan bahasa asing universal seperti bahasa Inggris supaya cakupan pangsa pasarnya lebih luas tidak terbatas pada daerah regional saja tapi juga bisa menyasar pada wisatawan asng.

Dalam pengertian sehari-hari, public relation dikenal dengan arti hubungan masyarakat, yaitu suatu bagian atau seksi dalam suatu keorganisasian yang tujuannya sebagai juru bicara bagi perusahaan dengan pihak lain yang memerlukan keterangan. Beberapa tahun yan glalu majalah Fortune mengartikan istilah public relation sebagai: "good performance, publicity appreciated because adequetly communicated", maksudnya sautu penampilan yang baik juga harus dikomunikasikan dengan baik supaya bisa diterima oleh publik. Public relation berguna menciptakan 
dan memelihara kesan yang positif tentang suatu destinasi tujuan wisata, Suatu public relation membutuhkan sales support. Sales support dapat diartikan sebagai bantuan pada penjual dengan memberikan semua bentuk informasi wisata yang direncaknakan dan diberikan kepada umum. Sales support tidak lain adalah kegiatan yang mendakan kontak-kontak secara pribadi (baik secara langsung maupun tidak langsung) kepada customer dalam hal ini wisatawan dengan tujuan memberitahu produk/service yang tersedia atau disediakan dan memberikan motivasi pada mereka untuk melakukan kegiatan penjualan. Sales support merupakan channel of communicationantara pengelola destinasi tujuan wisata dengan penyedia jasa-jasa yang lain. Sales support juga merupakan alat bantu yang efektif bagi pengelola tempat wisata. Beberapa sales support yang banyak digunakan adalah: brosur, folder, leaflets danguide-book.

Dalam melakukan pemilihan sasaran direct marketing perlu diperhatikan mengenai perilaku dan motivasi wisata dari pangsa pasar, situasi atau keadaan ekonomi, keadaan dan kecenderungan sosial serta waktu (timing) pemasaran.

Dari uraian teori-teori tersebut, maka dapat dilakukan beberapa solusi yang melibatkan berbagai pihak. Pihak-pihak yang diperkirakan dapat membantu dalam mengimplementasikan metode direct marketing untuk meningkatkan minat wisata wisatawan makam mbah Honggo di Kampung Kayutangan Kota Malang adalah Dinas Pariwisata Kota Malang, pemerintah atau pejabat di kampung Kayutangan, kelompok ibu-ibu PKK kampung Kayutangan, serta masyarakat sekitar kampung makam Mbah Honggo.

Adapun uraian peran-peran pihak tersebut adalah: (1) Dinas Pariwisata Kota Malang membanttu dalam legalitas informasi-informasi mengenai sejarah makam mbah Honggo serta membantu dalam halhal perijinan. (2) Pemerintah atau pejabat kampung Kayutangan diharakan mampu mempersiapkan lokasi makam mbah Honggo serta membentuk kelompo sadar wisata 
(POKDARWIS) yang melibatkan warga sekitar sebagai pelaku direct marketing-nya. Serta melakukan pelatihan untuk warga sebagai pemasar. (3) kelompok ibu-ibu PKK diharapkan berperan aktif untuk mendukung pembuatan alat pemasaran seperti guide-book dan brosur. Di sisi lain juga ibu-ibu PKK juga dapat berperan untuk membuat produk-produk yang bisa dijual sebagai oleh-oleh khas sehingga menambah nilai positif dari direct marketing yang akan dilakukan oleh POKDARWIS. (4) Masyarakat kampung Kayutangan berperan merawat dan menjaga area makam mbah Honggo. Selain itu, diharapkan warga juga bisa berperan aktif untuk mempromosikan destinasi wisatanya.

Adapun langkah-langkah yang dapat ditempuh untuk mengimplementassikan program direct-marketing tersebut adalah: Tahap pertama adalah pengumpulan informasi mengenai sejarah-sejarah dan literatur mengenai makam Mbah Honggo dengan melibatkan Dinas Pariwisata dan keturunan-keturunan dari mbah Honggo yang juga masih termasuk warga sekitar serta pembenahan area makam mah Honggo termasuk fasilitas-fasilitas pendukungnya seperti taman di area makam, tempat souvenir, dll. Selain itu, pemerintah daerah kampung Kayutangan juga bisa membentuk POKDARWIS yang khusus untuk menangani area makam mbah Honggo tersebut. Anggota POKDARWIS bisa diambil dari warga sekitar dan anggota ibu-ibu PKK. Peran-peran ibu-ibu PKK di sini diharapkan juga bisa memberikan ide-ide untuk memberikan sarana pendukung wisata makam mbah Honggo yang dapat memberikan nilai positif untuk destinasi wisata ini seperti kerajinan tangan atau olahan makanan khas.

$$
\text { Tahap kedua adalah }
$$
pembuatan alat pemasaran dalam hal ini yang dapat diimplementasikan adalah pembuatanguide-book dan brosusr berdasarkan informasiinformasi yang didapat pada tahap pertama. Pembuatan guide-book dan brosur ini bisa melibatkan warga sekitar dan kelompok ibu-ibu PKK karena diperlukan ide-ide otentik suaya tampilan lebih menarik. 
Selanjutnya guide-book tersebut bisa dipatenkan kepada dinas Pariwisata terkait.

Tahap ketiga adalah pelatihan dwi-bahasa dalam hal ini bahasa Indonesia dan bahsa Inggris kepada seluruh warga terasuk POKDARWIS dan kelompok ibu-ibu PKK supaya sasaran pemasaran nantinya tidak terbatas pada wisatawan domestik tapi juga wisatawan asing. Perilaku wisatawan asing cenderung lebih menyukai wisata yang tradisional atau otentik seperti wisata religi makam Mbah Honggo ini sehingga diperlukan suatu kemampuan berbahasa yang baik. Oleh karena itu pelatihan berbahasa Inggris juga perlu dilakukan secara kontinu.

Tahap keempat adalah pelaksanaan direct-marketing oleh bagian-bagian perrsonal/kelompok yang sudah ditunjuk. Hal ini dapat dilakukan dengan marketing lokal seperti berkeliling di area Kota Malang, mengadakan presentasi dengan penyedia usaha perjalanan wisata, hotel, sekolah-sekolah baik yang berbasis nasional maupuh internasional, warga asing serta juga bisa menawarkan paket wisata kepada instansi-instansi terkait. Diharapkan pelaksanaan direct-marketing ini bisa diterapkan tidak hanya pada kegiatankegiatan atau moment tertentu tapi juga keseharian.

Tahap kelima adalah evaluasi dari direct-marketing yang telah dilakukan. Diharapkan mampu meningkatkan pengetahuan dan minat wisatawan datang ke area makam Mbah Honggo. Serta perbaikan terusmenerus supaya area sasaran direct marketing semakin luas.

\section{KESIMPULAN}

Besarnya potensi wisata di pusat Kota Malang harus didukung dengan strategi pemasaran yang baik. Strategi pemasaran yang tepat dapat meningkatkan minat dan pengetahuan wisatawan terhadap wisata religi makam Mbah Honggo yang berada tepat di pusat Kota Malang. Supaya gagasan ini terwujud harus ada teknik untuk mengimplementasikannya. Di sini penulis menggunakan teori pemasaran wisata yang dikemukakan oleh Oka A. Yoeti dalam bukunya yang berjudul Pemasaran Pariwisata 
dan Alison Morrison dalam buknya yang berjudul Entrrepreneurshi in the Hospitality, Tourism and Leisures Industries. Secara garis besar teknik pemasaran yang paling efektif adalah menggunakan direct-marketing karena langsung menuju pada pasar sasaran. Beberapa tahap yang diperlukan adalah Persiapan komunikasi, alat pemasaran dan komunikasi, perencanaan kegiatan pemasaran, implementasi, dan evaluasi.

Diharapkan dengan adanya direct-marketing makam mbah Honggo dikawasan kampung Kayutangan kota
Malang dapat menjadi salah satu ikon wisata religi yang diminati di pusat Kota Malang.

\section{DAFTAR RUJUKAN}

Morisson, $\quad 1999$. Entrepreneurship in the Hospitality, Tourism and Leisures Industries. Butterworth Heinemann : Oxford

Wahab, Salah. dkk. 1997. Pemasaran Pariwisata. Pradnya Paramitha : Jakarta

Yoeti, Oka.A. 1996. Pemasaran Pariwisata. Angkasa : Bandung 